\title{
ANALISIS KESALAHAN MATEMATIKA KONSEP OPERASI HITUNG BILANGAN BULAT MAHASISWA CALON GURU SEKOLAH DASAR
}

\author{
Andri Anugrahana \\ PGSD, Universitas Sanata Dharma \\ Email:andrianugrahana@gmail.com
}

\begin{abstract}
Abstrak:
Penelitian ini bertujuan untuk menemukan bentuk-bentuk kesalahan yang dilakukan mahasiswa dalam menyelesaikan soal-soal yang berkaitan dengan operasi hitung bilangan bulat serta mencari faktor mahasiswa melakukan kesalahan. Subjek dalam penelitian ini adalah mahasiswa calon guru sekolah dasar PGSD Universitas Sanata Dharma. Mahasiswa diberikan soal dan dianalisis kesalahan dari mahasiswa dan dicari alasannya. Penelitian ini tergolong penelitian deskriptif kualitatif sehingga data yang ada dianalisis dengan teknik analisis data kualitatif. Dari hasil analisis data dapat disimpulkan bahwa: Kesalahan konseptual yang dilakukan mahasiswa : (1) operasi hitung campuran perkalian, penjumlahan dan pengurangan, (2) operasi hitung perkalian dan pengurangan, (3) operasi distribusi, (4) kurang memahami penjumlahan dan pengurangan sama kuat. (5) operasi hitung dari sebelah kiri dan menyamakan semua operasi hitung memiliki bentuk yang sama. Kesalahan prosedural yang dilakukan mahasiswa: (1) tidak melihat perbedaan antara operasi hitung campuran, melakukan kesalahan dengan operasi pengurangan terlebih dahulu, (2) mengumpulkan dengan subtitusi terlebih dahulu lalu dioperasikan, (3) tidak dapat menjumlahkan operasi hitung pengurangan dengan bilangan negatif. Faktor-faktor mahasiswa melakukan kesalahan: (1) mahasiswa tidak teliti dalam mengoperasikan operasi bilangan bulat, (2) mahasiswa buru-buru dalam mengerjakan soal, (3) mahasiswa binggung atau belum bisa membedakan setiap tanda operasi yang diberikan dalam soal, (4) mahasiswa tidak memahami aturan dalam operasi hitung bilangan bulat.
\end{abstract}

Kata Kunci: Analisis kesalahan, operasi bilangan bulat

\section{Pendahuluan}

Kesalahan konsep sering terjadi pada siswa maupun mahasiswa khususnya saat mengolah informasi yang diperoleh. Kesalahan konsep bisa terjadi sejak sekolah dasar, sekolah menengah sampai pada mahasiswa. Kesalahan konsep yang terjadi sejak sekolah dasar dan tidak segera diatasi mungkin dengan baik akan berdampak sampai pada tingkat yang lebih tinggi. Hal ini sejalan dengan pendapat Gradini (2016: 53) bahwa miskonsepsi yang berkelanjutan jika tidak ditangani secara tepat dan diatasi sedini mungkin, akan menimbulkan masalah pada pembelajaran selanjutnya. Suatu konsep akan saling berkaitan dengan konsep-konsep yang lainnya. Jika konsep dasar saja mengalami kesalahan maka pembentukan konsep selanjutnya juga akan mengalami kesalahan karena setiap konsep memiliki jalinan ataupun hubungan satu dengan yang lain. Hal ini didukung oleh pendapat Olivier menjelaskan bahwa kesalahan adalah jawaban yang salah karena perencanaan yang tidak tepat dan tidak sistematis yang diterapkan dalam menyelesaikan permasalahan matematika sedangkan miskonsepsi adalah gejala struktur kognitif yang menyebabkan kesalahan (Herutomo, 2014). Gradini (2016:53) juga menjelaskan lebih lanjut bahwa miskonsepsi merupakan penjelasan yang salah dan suatu gagasan yang tidak sesuai dengan pengertian ilmiah yang diterima para ahli. Miskonsepsi mencakup pemahaman atau pemikiran yang tidak berlandaskan pada informasi yang tepat. Artinya kesalahan ataupun miskonsepsi terjadi bisa karena pengalaman ataupun informasi yang diperoleh sebelumnya tidak relevan. Kesalahan konsep yang tidak teratasi dengan baik akan menjadi masalah yang berkelanjutan jika tidak diperbaiki. Kesalahan konsep biasanya banyak ditemukan pada mata pelajaran matematika karena menurut Novitasari (2016:8) matematika adalah materi pembelajaran yang saling berkaitan satu sama lain. Hal 
ini juga didukung oleh kesalahan konsep adalah kesalahan dalam menggunakan konsep-konsep yang terkait dengan materi. Kesalahan konsep dapat terjadi pada siswa di antaranya karena salah dalam memahami makna soal dan salah dalam menggunakan konsep variabel yang akan digunakan (Subaidah dalam Widodo 2013: 107).

Kesalahan konsep tidak hanya terjadi pada siswa sekolah dasar tetapi dapat juga terjadi pada calon guru sekolah dasar. Kesalahan yang dilakukan mahasiswa adalah kesalahan konsep yang sangat mendasar sekali. Jika kesalahan ini dibiarkan saja maka akan berdampak pada kesalahan-kesalahan yang berikutnya. Apalagi calon guru SD (mahasiswa Pendidikan Guru Sekolah Dasar/PGSD) (Amini dan Munandar, 2010) yang nantinya akan menjadi Pendidik bagi anak-anak sekolah dasar. Dan jika kesalahan sudah terjadi pada gurunya maka akan berdampak kesalahan konsep pada siswa SD. Maka LPTK yang merupakan lembaga yang menghasilkan tenaga pendidik (guru) dan tenaga kependidikan berusaha membekali berbagai pengetahuan bagi calon guru. Guru tidak hanya lulus sebagai sarjana pendidikan saja tetapi menjadi guru yang berani dan siap mengajar. Salah satu syarat menjadi guru guru SD wajib hukumnya bermutu tinggi, berwawasan luas, dan melek teknologi (Ibda dan Wijayanti,2014). Hal ini sejalan dengan UU Nomor 14 Tahun 2005 guru dan dosen, guru wajib memiliki kompetensi pedagogik, kompetensi kepribadian, kompetensi sosial, dan kompetensi profesional. Ini menunjukkan bahwa tuntutan guru semakin sulit maka penting calon guru mendapatkan bekal yang banyak agar dapat memberikan yang baik dan benar.

Kesalahan konsep terjadi pada mahasiswa khususnya pada mata kuliah pembelajaran matematika. Pembelajaran Matematika dapat dipandang sebagai usaha dosen dalam membantu mahasiswa, memahami atau terampil matematika. Hal ini nampak dari hasil observasi dosen pada mata kuliah pembelajaran matematika dimana mahasiswa melakukan simulasi matematika dengan mengajar di depan mahasiswa lainnya. Hasil observasi menunjukkan bahwa mahasiswa masih ada yang melakukan kesalahan- kesalahan konsep matematika saat menjelaskan. Kesalahan dilakukan mahasiswa pada konsep dasar yang seharusnya sudah dikuasi oleh mahasiswa. Ramlan (2017: 182) menjelaskan bahwa matematika adalah ilmu pengembangan daya pikir manusia. Maka penting bagi mahasiswa untuk menguasai konsep matematika sehingga ketika menjadi guru mampu mengembangkan daya pikir siswa di sekolah. Zayyadi dan Kurniati (2018) menjelaskan aktivitas matematika melibatkan dua jenis penalaran antara lain penalaran dihasilkan oleh dugaan, dan penalaran melalui pengetahuan matematika yang terbukti. Masalah dalam matematika adalah pertanyaan atau soal yang harus diselesaikan atau direspon (Aini, 2017; Zayyadi dan Subaidi, 2018). Artinya mahasiswa sebagai calon guru di sekolah dasar yang juga akan mengajar matematika perlu dapat menjelaskan konsep pada siswa. Meskipun matematika masih diangap mata kuliah yang sulit, hal ini sejalan dengan hasil penelitian Primasatya yang menjelaskan bahwa matematika sebagai salah satu bidang yang dianggap menakutkan, begitu juga bagi calon guru sekolah dasar.

Peran guru membantu siswa belajar matematika maka guru perlu tahu bagaimana sebenarnya jalan atau proses matematika itu bisa dipahami atau dikuasai oleh siswa. Dalam hal ini guru harus memiliki pengetahuan pedagogik yang baik (Zayyadi, dkk, 2020). Jika tidak demikian tentu sulit bagi seorang guru untuk membantu siswanya belajar matematika (Sutawidjaja dan Dahlan, 2014). Kesalahan konsep misalnya -4 dikali dengan -4 dan hasilnya adalah 16, maka mahasiswa akan mengatakan bahwa " memang seperti ini negative ketemu negative hasilnya positif", saat ditanya lebih lanjut, ya memang seperti itu yang mahasiswa pahami. Tidak hanya itu saja keprihatinan pada kesalahan konsep mahasiswa adalah saat menggambar garis bilangan, mahasiswa mengalami kesalahan bahwa ke kanan possitif dan ke kiri negatif. Hal ini ternyata mempengaruhi mahasiswa saat mengerjakan soal garis bilangan. 
Mahasiswa kesulitan menggambarkan garis bilangan negatif 4 dikali negatif 4 hasilnya adalah delapan. Kesalahan konsep diduga kuat terbentuk pada masa anak dalam interaksi otak dengan alam. Sejak kecil anak berpengalaman dengan alam di sekitarnya, anak yang menggerakkan mainan telah memperoleh pengalaman yang berhubungan dengan konsep gaya, momentum, kecepatan, dan percepatan, walaupun istilah itu memang belum digunakan. Maka di dalam otaknya sudah terbentuk konsepsi atau miskonsepsi yang berhubungan dengan konsep-konsep tersebut. Hal ini didukung oleh hasil penelitian yang dilakukan.

Penelitian ini menjelaskan secara mendalam kesalahan mahasiswa dalam melakukan operasi hitung bilangan bulat. Bilangan bulat merupakan bilangan yang terdiri dari semua bilangan negatif, 0 dan semua bilangan positif. Contoh bilangan bulat yaitu ...-3, -2, -1, $0,1,2,3 \ldots$ dan seterusnya. (Widyaningrum, 2013). Kastolan (dalam Sahriah, 2012) membagi kesalahan menjadi dua yaitu (1) Kesalahan konsep adalah kesalahan yang dilakukan siswa dalam menafsirkan istilah, konsep, dan prinsip. Atau salah dalam menggunakan istilah, konsep dan prinsip. Indikator kesalahan konseptul adalah sebagai berikut :a) Salah dalam menentukan rumus atau teorema atau defenisi untuk menjawab suatu masalah, b) Penggunaan rumus, teorema, atau definisi yang tidak sesuai dengan kondisi prasyarat berlakunya rumus, teorema, atau definisi tersebut. c) Tidak menuliskan rumus, teorema atau definisi untuk menjawab suatu masalah. (2) Kesalahan prosedural adalah kesalahan dalam menyusun langkah-langkah yang hirarkis sistematis untuk menjawab suatu masalah. Indikator kesalahan prosedural menurut Kastolan adalah sebagai berikut: a) Ketidakhirarkisan langkah-langkah dalam menyelesaikan masalah-masalah, b) Kesalahan atau ketidakmampuan memanipulasi langkah-langkah untuk menjawab suatu masalah.

Matematika adalah salah satu mata kuliah yang wajib ditempuh oleh mahasiswa, dimana mahasiswa mendapatkan bekal matematika dasar.
Berdasarkan pengalaman peneliti sebagai dosen pengampu mata kuliah matematika, meskipun materi mengulang materi di sekolah namun sebagian besar mahasiswa masih mengalami kesulitan dalam memahami dan menyelesaikan beberapa masalah operasi bilangan bulat.

Tentunya hal ini tidak bisa dibiarkan begitu saja, mengingat mahasiswa program PGSD merupakan mahasiswa calon guru sekolah dasar yang akan mendidik anakanak sekolah dasar. Hal ini melatarbelakangi peneliti untuk analisis kesalahan mahasiswa calon guru sekolah dasar dalam memahami operasi hitung campuran. Sehingga tujuan dari penelitian ini adalah menemukan bentuk-bentuk kesalahan yang dilakukan mahasiswa dalam menyelesaikan soal-soal yang berkaitan dengan operasi hitung bilangan bulat serta faktor mahasiswa melakukan kesalahan.

\section{Metode Penelitian}

Jenis penelitian yang digunakan adalah penelitian kualitatif deskriptif. penelitian kualitatif adalah suatu penelitian yang ditujukan untuk mendekripsikan dan menganalisis fenomena, peristiwa, aktivitas sosial, sikap, kepercayaan, persepsi, pemikiran orang secara individual maupun kelompok. Beberapa deskripsi digunakan untuk menemukan prinsip-prinsip dan penjelasan yang mengarah pada penarikan kesimpulan (Bachri, 2010). Penelitian ini mendiskripsikan dan menganalisis kesalahan mahasiswa calon guru sekolah dasar dalam operasi hitung bilangan bulat. Subjek dalam penelitian ini adalah mahasiswa calon guru sekolah dasar PGSD Universitas Sanata Dharma dengan jumlah mahasiswa 45. Instrumen yang digunakan dalam penelitian ini adalah peneliti sendiri sebagai instrumen utama dan instrumen pendukung adalah tes, pedoman wawancara dan juga lebar observasi. Analisis data dilakukan dengan proses reduksi data dan penyajian data, selanjutnya diakhiri dengan penarikan kesimpulan dari hasil analisis. Ellis (dalam Tarigan dan Tarigan, 2011) menyatakan terdapat lima langkah kerja analisis, yaitu: (1) pengumpulan sampel, (2) pengidentifikasian kesalahan, 
kesalahan, dan (5) pengevaluasian kesalahan. Peneliti menganalisa dua pertanyaan berkaitan dengan operasi hitung campuran. Untuk soal yang berkaitan dengan operasi hitung campuran penjumlahan dan pengurangan dan juga perkalian.

\section{Hasil dan Pembahasan}

Tujuan dari soal ini adalah untuk melihat kesalahan konsep yang dilakukan oleh mahasiswa calon guru SD. Asumsinya adalah calon guru harus sudah memiliki bekal yang kuat untuk menggajar. Khususnya calon guru SD harus sudah memiliki bekal dan menguasai matematika dasar. Dalam hal ini khususnya konsep bilangan bulat materi operasi hitung. Analisa pada operasi hitung penjumlahan, pengurangan, dan perkalian. Berikut adalah soal operasi hitung perkalian bilangan negatif : $-4 \mathrm{x}-4=16$. Jawaban mahasiswa adalah negative dikali dengan negative adalah positif. Berikut adalah jawaban mahasiwa "ya memang sudah seperti itu $b u$ " (transkrip komunikasi pribadi, Desember 2019). Mahasiswa kesulitan dalam menjelaskan dan memberikan alasan bagaimana proses perhitungan yang dilakukan oleh mahasiswa. Analisa untuk soal operasi hitung campuran yaitu soal operasi hitung : $11 \times 12+12 \times 13-13 \times$ $14+14 \times 15$. Prinsip dalam mengerjakan soal ini adalah mahasiswa memahami langkah dalam mengerjakan soal hitungan campuran yaitu dari kiri ke kanan dan mahasiwa memahami operasi hitung campuran mana yang lebih kaut dan mana yang sama kuat antara operasi hitung penjumlahan, pengurangan, perkalian dan juga pembagian. Permasalahan yang disampaikan ke mahasiswa adalah operasi penjumlahan dan pengurangan. Tetapi pada operasi hitung campuran yang diberikan tidak menggunakan tanda kurung. Soal yang disampaikan adalah $11 \times 12+12$ x $13-13$ x $14+14$ x $15=$. Berikut adalah kesalahan-kesalahan yang dilakukan oleh mahasiswa tampak pada uraian berikut ini.

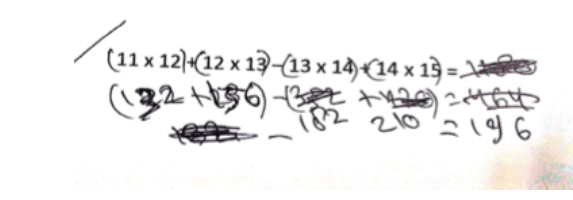

\section{Gambar 1. Kesalahan Pertama Mahasiswa}

Gambar 1 ini menunjukkan bahwa
mahasiswa tidak teliti $r$
mengoperasikan penjumlahan dan
pengurangan. Meskipun hanya ada 1
mahasiswa yang menjawab demikian, hal
ini menunjukkan masih ada kesalahan dan
ketidaktelitian dari mahasiswa.

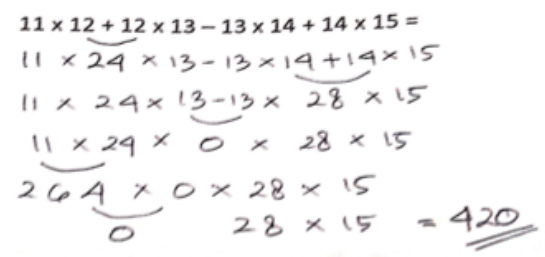

Gambar 2. Kesalahan Kedua Mahasiswa

Hasil jawaban pada gambar 2 membuktikan menjelaskan bahwa awalnya mahasiswa sudah melakukan langkah yang tepat hanya saja saat akan mengoperasikan perkalian dan pengurangan, mahasiswa melakukan kesalahan dengan mengurangkan 13 dengan 13. Hal ini menunjukkan ketidakpahaman mahasiswa mengenai langkah mana yang harus dikerjakan terlebih dahulu saat menemukan masalah matematika dan pengurangan. Ada 2 mahasiwa menjawab seperti gambar 2. Artinya mahasiswa masih mengoperasikan pengurangan dulu lalu dikalikan.

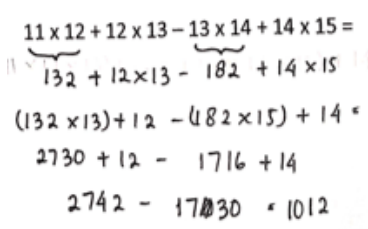

\section{Gambar 3. Kesalahan Kedua Mahasiswa}

Gambar 3 menjelaskan bahwa mahasiswa memahami bahwa $182+14 \mathrm{x}$ 15 itu sama artinya dengan $182 \times 15$ dulu selanjutnya dioperasikan dengan 
menjumlahkan dengan 14. Hal ini membuktikan bahwa mahasiswa mengalami kesalahan antara operasi hitung campuran penjumlahan dan perkalian. ada 2 mahasiwa menjawab seperti gambar ke 2 .

$$
\begin{aligned}
& 11 \times 12+12 \times 13-13 \times 14+14 \times 15=326 \\
& (11 \times 12)+(12 \times 13)-(13 \times 14)+(14 \times 15) \\
& 132+156-172+210 \\
& (288-172)+210 \\
& 326
\end{aligned}
$$

\section{Gambar 4. Kesalahan Keempat Mahasiswa}

Pada gambar 4 ini, 28 mahasiswa melakukan kesalahan. Pada gambar 4 tampak sebetulnya mahasiwa sudah mengelompokkan dan mendahulukan operasi hitung bentuknya adalah perkalian. Hal ini ditunjukkan dengan memberi tanda kurung dan melakukan operasi perkalian terlebih dahulu pada operasi dalam kurung. Selanjutnya menuliskan hasil perhitungan perkalian di bawah tanda dalam kurung, sudah tepat. Hanya ketidaktelitian mahasiswa dalam mengoperasikan penjumlahan dan pengurangan.

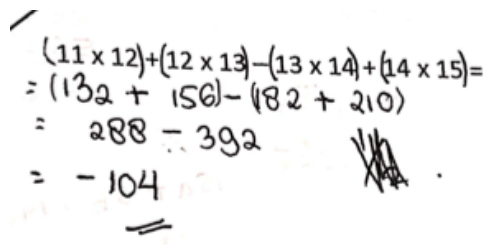

\section{Gambar 5. Kesalahan Kelima Mahasiswa}

Pada gambar 5 total kesalahan yang dilakukan mahasiswa ada 84 mahasiswa melakukan kesalahan. Miskonsepsi yang dilakukan mahasiswa adalah mahasiswa keliru dalam mengoperasikan penjumlahan dan pengurangan. Miskonsepsi pada mahasiswa adalah mengoperasikan penjumlahan dahulu selanjutnya baru operasi pengurangan. Mahasiswa mengoperasikan penjumlahan terlebih dahulu dengan asumsi bahwa sama kuat antara penjumlahan dan pengurangan. Argumen dari mahasiswa tersebut benar tetapi mahasiswa perlu memperhatikan bahwa ketika dioperasikan bersama-sama dengan bentuk operasi yang lainnya maka penjumlahan dan pengurangan dapat dikerjakan dari sebelah kiri.

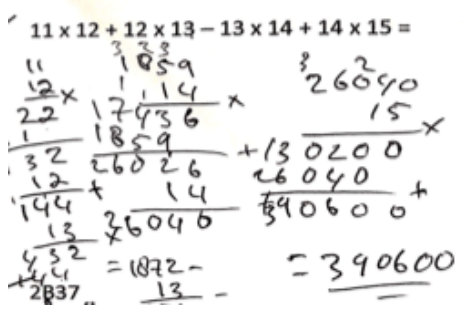

\section{Gambar 6. Kesalahan Keenam Mahasiswa}

Gambar 6 menunjukkan jawaban tidak menjawab dari apa yang ditanyakan dijawab oleh 8 mahasiswa. Kesalahpahaman nampak dari tulisan mahasiswa dimana mahasiswa masih menghitung mulai dari mengalikan 11 dengan 12 dan hasil perkalian dijumlahkan dengan 12. Selanjutnya dikalikan dengan 13 dan dikurangi 13. Setelah dikurangi dilakukan operasi perkalian dengan 14 dan menjumlahkan dengan 14 dan terakhir dikalikan dengan 15 .

$$
11 \times 12+12 \times 13-13 \times 14+14 \times 15=104
$$

\section{Gambar 7. Kesalahan Ketujuh Mahasiswa}

Ada 2 mahasiswa melakukan kesalahan pada gambar 7 .

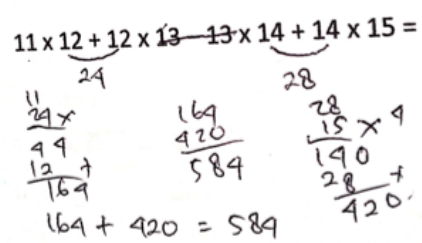

\section{Gambar 8. Kesalahan Kedelapan Mahasiswa}

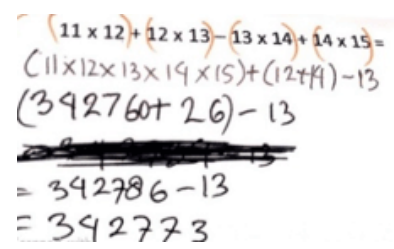

Gambar 9. Kesalahan Kesembilan Mahasiswa

Ada 1 mahasiswa menjawab seperti gambar 9. Kesalahan yang dilakukan mahasiswa mengumpulkan dengan subtitusi 
terlebih dahulu lalu dioperasikan. Pada soal yang berbeda, juga ditemukan beberapa kesalahan operasi yang dilakukan mahasiswa. Soal yang disampaikan adalah $10+(-5)-(-8)$.

$$
\begin{aligned}
& 10+(-5)-(-8)= \\
= & 10+(-5)-(-8) \\
= & 5-(-8) \\
= & -3
\end{aligned}
$$

\section{Gambar 10. Kesalahan Kesepuluh Mahasiswa}

Gambar 10 merupakan kesalahan mahasiswa tidak dapat menjumlahkan operasi hitung pengurangan dengan bilangan negatif.

$$
\begin{aligned}
& 10+(-5)-(-8)= \\
= & 10+(-5)+(8) \\
= & 5-8 \\
= & -3
\end{aligned}
$$

\section{Gambar 11. Kesalahan Kesebelas Mahasiswa}

Gambar 11 adalah kesalahan pada operasi hitung penjumlahan dengan bilangan negatif dan juga pengurangan dengan bilangan negatif.

$$
\begin{aligned}
& : \quad 10+(-5)-(-8)= \\
& \text { iwob: } \\
& 10+(-5)-(-8) \\
& : 10+(-3) \\
& =7 .
\end{aligned}
$$

\section{Gambar 12. Kesalahan Ketigabelas} Mahasiswa

$$
\begin{aligned}
& 10+(-5)-(-8)= \\
& 10+13=23
\end{aligned}
$$

\section{Gambar 13. Kesalahan ketigabelas mahasiswa}

Gambar 12 dan Gambar 13 adalah kesalahan pada operasi pengurangan bilangan negatif dengan bilangan negatif. Tidak hanya itu saja pada gambar 13 juga menjelaskan bahwa kesalahan juga nampak dari operasi penjumlahan dengan bilangan negatif $10+(-5)=10$, ini artinya mahasiswa masih kesulitan melakukan operasi penjumlahan dengan bilangan negatif. Analisis kesalahan yang dilakukan mahasiswa sebagai berikut:

(1) Gambar 1 merupakan kesalahan mahasiswa dalam konsep operasi hitung campuran penjumlahan dan pengurangan

(2) Gambar 2 merupakan kesalahan konsep hitung perkalian dan pengurangan. Artinya mahasiswa masih mengoperasikan pengurangan dulu lalu dikalikan

(3) Gambar 3 merupakan kesalahan konsep operasi hitung campuran penjumlahan dan perkalian

(4) Gambar 4 dan 5 merupakan kesalahan konsep mahasiswa kurang memahami penjumlahan dan pengurangan sama kuat. mengoperasikan penjumlahan dahulu selanjutnya baru operasi pengurangan. Mahasiswa mengoperasikan penjumlahan terlebih dahulu dengan asumsi bahwa sama kuat antara penjumlahan dan pengurangan. Argumen dari mahasiswa tersebut benar tetapi mahasiswa perlu memperhatikan bahwa ketika dioperasikan bersamasama dengan bentuk operasi yang lainnya maka penjumlahan dan pengurangan dapat dikerjakan dari sebelah kiri.

(5) Gambar 6 merupakan kesalahan mahasiswa adalah melakukan operasi hitung dari sebelah kiri dan menyamakan semua operasi hitung memiliki bentuk yang sama

(6) Gambar 7 dan 8 merupakan kesalahan mahasiswa tidak melihat perbedaan antara operasi hitung campuran, melakukan kesalahan dengan operasi pengurangan terlebih dahulu.

(7) Gambar 9 merupakan kesalahan mahasiswa mengumpulkan dengan subtitusi terlebih dahulu lalu dioperasikan

(8) Gambar 10 merupakan kesalahan mahasiswa tidak dapat menjumlahkan operasi hitung pengurangan dengan bilangan negatif. 
(9) Gambar 11, gambar 12, dan gambar 13 menunjukkan kesalahan dalam mengoperasikan operasi hitung pengurangan dan penjumlahan dengan bilangan negatif.

Sejalan dengan penjelasan ini, Van deWalle (dalam Utomo, 2012) mengemukakan bahwa pengetahuan konseptual memuat relasi-relasi (antar konsep matematika) dan keterkaitan relasi tersebut dengan konsep matematika yang lain. Apabila dilihat dari beberapa kesalahan : (1) kesalahan konsep hitung campuran perkalian, penjumlahan dan pengurangan. (2) kesalahan konsep hitung perkalian dan pengurangan. Artinya mahasiswa masih mengoperasikan pengurangan dulu lalu dikalikan. (3) kesalahan konsep operasi distribusi, mahasiswa mengalami miskonsepsi antara operasi hitung campuran dengan langkah distribusi dalam matematika. (4) kesalahan konsep kurang memahami penjumlahan dan pengurangan sama kuat. (5) kesalahan melakukan operasi hitung dari sebelah kiri dan menyamakan semua operasi hitung memiliki bentuk yang sama. Hiebert\&Lefevre (dalam Van DeWalle, 1990) mengemukakan bahwa pengetahuan procedural adalah pengetahuan tentang simbol untuk merepresentasikan idea matematika serta aturan dan prosedur yang digunakan untuk menyelesaikan tugas matematika (dalam Utomo, 2012). Kesalahan prosedural yang dilakukan mahasiswa sebagai berikut: (1) kesalahan tidak melihat perbedaan antara operasi hitung campuran, melakukan kesalahan dengan operasi pengurangan terlebih dahulu. (2) kesalahan mengumpulkan dengan subtitusi terlebih dahulu lalu dioperasikan. (3) kesalahan tidak dapat menjumlahkan operasi hitung pengurangan dengan bilangan negatif.

Faktor-faktor siswa melakukan kesalahan antara lain: (1) mahasiswa tidak teliti dalam mengoperasikan operasi bilangan bulat. Hal ini nampak dari gambar 11 dimana mahasiswa menuliskan angka penjumlahan delapan menjadi negative delapan. Hal ini juga didukung dari hasil wawancara lebih lanjut bahwa mahasiswa juga mengatakan hal yang sama bahwa kesalahannya adalah tidak teliti. "saya paham bu bahwa negatif ketemu dengan negatif hasilnya adalah positif" (transkrip komunikasi pribadi, Desember 2019). (2) mahasiswa buru-buru dalam mengerjakan soal. Hal ini didukung dengan hasil wawancara "waktunya terlalu cepetbu, saya butuh waktu" (transkrip komunikasi pribadi, Desember 2019), (3)mahasiswa binggung atau belum bisa membedakan setiap tanda operasi yang diberikan dalam soal. Hal ini sudah nampak dari setiap gambar kesalahan-kesalahan yang dilakukan oleh mahasiswa. Hasil wawancara lebih lanjut juga menyebutkan bahwa "saya belum hafal bu", (transkrip komunikasi pribadi, Desember 2019). Tidak hanya itu saja (4) mahasiswa tidak memahami aturan dalam operasi hitung campuran. Hal ini dapat dilihat dari gambar 6 dari jawaban siswa yang hanya asal saja dalam mengerjakan. Dan saat wawancara lebih lanjut alasannya juga sama bahwa "saya tidak hafal bu", "saya tidak bisa bu”, "saya tidak suka di pgsdbu" (transkrip komunikasi pribadi, Desember 2019).

\section{Simpulan dan Saran}

Kesimpulan Kesalahan matematika konsep bilangan bulat dibagi menjadi dua yaitu kesalahan konseptual dan kesalahan procedural. Kesalahan konseptual yang dilakukan mahasiswa : kesalahan konsep (1) operasi hitung campuran perkalian, penjumlahan dan pengurangan, (2) operasi hitung perkalian dan pengurangan, (3) operasi distribusi, (4) kurang memahami penjumlahan dan pengurangan sama kuat. (5) operasi hitung dari sebelah kiri dan menyamakan semua operasi hitung memiliki bentuk yang sama. Kesalahan prosedural yang dilakukan mahasiswa: (1) tidak melihat perbedaan antara operasi hitung campuran, melakukan kesalahan dengan operasi pengurangan terlebih dahulu, (2) mengumpulkan dengan subtitusi terlebih dahulu lalu dioperasikan, (3) tidak dapat menjumlahkan operasi hitung pengurangan dengan bilangan negatif. Faktor-faktor mahasiswa melakukan kesalahan: (1) mahasiswa tidak teliti dalam mengoperasikan operasi bilangan bulat, (2) mahasiswa buru-buru dalam mengerjakan 
soal, (3) mahasiswa binggung atau belum bisa membedakan setiap tanda operasi yang diberikan dalam soal, (4) mahasiswa tidak memahami aturan dalam operasi hitung campuran. Saran untuk penelitian selanjutnya adalah analisis kesalahan konsep pada mahasiswa dapat menggunakan metode analisis yang lainnya seperti CRI (certainty of response indeks). Selain itu soal yang diberikan dapat dibuat lebih bervariasi.

\section{Daftar Pustaka}

Aini, S. D., Jannah, U. R., \& Masruroh, R. (2017). Identifikasi Kesalahan Siswa dalam Menyelesaikan Masalah Trigonometri. Sigma, 3(1), 17-25.

Amini, R., \& Munandar, A. (2010). Pengaruh model pembelajaran pendidikan lingkungan berbasis outdoor terhadap penguasaan konsep pendidikan lingkungan bagi calon guru sekolah dasar. Jurnal Penelitian Pendidikan, 11(1), 14-21.

Bachri, B. S. (2010). Meyakinkan validitas data melalui triangulasi pada penelitian kualitatif. Jurnal Teknologi Pendidikan, 10(1), 46-62.

Gradini, E. (2016). Miskonsepsi dalam Pembelajaran Matematika Sekolah Dasar di Dataran Tinggi Gayo. NumeracyJournal, 3(2).

Ibda, H., \& Wijayanti, D. M. (2014). Siapkah Saya Menjadi Guru SD Revolusioner?. Kalam Nusantara

Novitasari, D. (2016). Pengaruh penggunaan multimedia interaktif terhadap kemampuan pemahaman konsep matematis siswa. FIBONACCI: Jurnal Pendidikan Matematika dan Matematika, 2(2), 8-18.

Primasatya, N. (2016). Analisis Kemampuan Berpikir Matematis Calon Guru Sekolah Dasar Dalam Menyelesaikan Masalah Matematika. JPM: Jurnal Pendidikan Matematika, 2(1), 50-57.
Tayubi, Y. R. (2005). Identifikasi miskonsepsi pada konsep-konsep fisika menggunakan CertaintyofResponse Index (CRI). Mimbar Pendidikan, 3(24), 4-9.

Ramlah, R., Bennu, S., \&Paloloang, B. (2017). Analisis Kesalahan Siswa dalam Menyelesaikan Soal Penjumlahan dan Pengurangan Pecahan Di Kelas VII SMPN Model Terpadu Madani. JIPMat, 1(2).

Herutomo, R. A., \& Saputro, T. E. M. (2014). Analisis kesalahan dan miskonsepsi siswa kelas VIII pada materi aljabar. Edusentris, 1(2), 134145.

Sahriah, S. (2013). Analisis Kesalahan Siswa dalam Menyelesaikan Soal Matematika Materi Operasi Pecahan Bentuk Aljabar Kelas VIII SMP Negeri 2 Malang. SKRIPSI Jurusan Teknik Mesin-Fakultas Teknik UM.

Sutawidjaja, A., \& Dahlan, J. A. (2014). Pembelajaran matematika.

Tarigan, Henry Guntur dan Djago Tarigan. 2011. Pengajaran Analisis Kesalahan Berbahasa. Bandung: Angka

Utomo, D. P. (2012). Pengetahuan Konseptual dan Prosedural dalam Pembelajaran Matematika. Jurnal Prosiding Matematika, 1(1), 21-31.

Undang-Undang Nomor 14 Tahun 2005 http://kompetensi.info/kompetensiguru/empat-kompetensi-guru.html

Widodo, S. A. (2013). Analisis kesalahan dalam pemecahan masalah divergensi tipe membuktikan pada mahasiswa matematika. Jurnal pendidikan dan pengajaran, 46(2 Juli).

Widyaningrum, H. (2013). Meningkatkan Hasil Belajar Pengurangan Bilangan Bulat Menggunakan Media Wajah Lucu dari Flanel di Sekolah Dasar. Jurnal Penelitian Pendidikan Guru Sekolah Dasar, 1(2), 1-10 
Zayyadi, M., \& Subaidi, A. (2018). Berpikir Kritis Mahasiswa dalam Memecahkan Masalah Aljabar. Paedagoria: Jurnal Kajian, Penelitian dan Pengembangan Kependidikan, $8(2), 10-15$.

Zayyadi, M., \& Kurniati, D. (2018). Mathematics reasoning and proving of students in generalizing the pattern. International Journal of
Engineering \& Technology, 7(2), 1517.

Zayyadi, M, Nusantara, T, Hidayanto, E , Sulandra, I Made, Sa'dijah, C. (2020). Content and Pedagogical Knowledge of Prospective Teachers in Mathematics Learning: Commognitive Framework. Journal for the Education of Gifted Young Scientists, 8 (1), 515-532 